\title{
Assessing movement of the California sea cucumber Parastichopus californicus in response to organically enriched areas typical of aquaculture sites
}

\author{
Paul van Dam-Bates ${ }^{1}$, Daniel L. Curtis ${ }^{2}$, Laura L. E. Cowen ${ }^{1}$, Stephen F. Cross ${ }^{3}$, \\ Christopher M. Pearce ${ }^{2, *}$ \\ ${ }^{1}$ Department of Mathematics and Statistics, University of Victoria, Victoria, British Columbia V8P 5C2, Canada \\ ${ }^{2}$ Pacific Biological Station, Fisheries and Oceans Canada, Nanaimo, British Columbia V9T 6N7, Canada \\ ${ }^{3}$ Department of Geography, University of Victoria, Victoria, British Columbia V8P 5C2, Canada
}

\begin{abstract}
An increasing global demand for sea cucumbers has led to interest in benthic ranching of the California sea cucumber Parastichopus californicus beneath existing aquaculture sites in British Columbia, Canada, where high levels of total organic matter (TOM) are typical. The objective of the present study was to investigate movement of $P$. californicus in relation to areas of increased organic content to assess the feasibility of sea cucumber ranching beneath existing aquaculture sites. A laboratory experiment using adult sea cucumbers showed that $P$. californicus changed their foraging behaviour based on available amounts of TOM, moving more randomly in high-TOM ( 8.0\%) areas and more directly in low-TOM $(\sim 1.4 \%)$ ones. They also moved more rapidly in areas with high TOM than in those with low TOM. As long as animals were exposed to high TOM, they did not abandon random movement. Because of this behaviour, aquaculture tenures may retain a population of cultured individuals, but could also attract wild individuals from the surrounding area.
\end{abstract}

KEY WORDS: Aquaculture $\cdot$ California sea cucumber $\cdot$ Foraging $\cdot$ Movement $\cdot$ Parastichopus californicus $\cdot$ Sea ranching $\cdot$ Holothurian

\section{INTRODUCTION}

Sea cucumbers have been an important food source for centuries in Asia and have been harvested in China for over 400 yr (Schwerdtner Máñez \& Ferse 2010). In the past few decades, however, an increasing demand for holothurians from Asian markets has created a major global fishery that has led to overexploitation and declines in stocks in many parts of the world (Conand 2004, Anderson et al. 2011, Friedman et al. 2011, Purcell et al. 2013). As a result, strong sea cucumber aquaculture industries have developed in many countries including China, Indonesia, Russia and Vietnam (FAO 2011). Sea cucumbers may be co-cultured in intertidal ponds

\footnotetext{
${ }^{*}$ Corresponding author: chris.pearce@dfo-mpo.gc.ca
}

with shrimp or bivalves, grown in suspended cages or trays or ranched on the sea floor either in pens or without containment (James et al. 1994, Chen 2003, Wang \& Cheng 2004). Despite growing interest in their culture, and despite significant commercial aquaculture advances that have been made with Apostichopus japonicus and Holothuria scabra (Robinson 2013, Yang et al. 2015), there is a general lack of information about the ecology and biology of most species of sea cucumbers of commercial interest (Lovatelli et al. 2004).

This lack of knowledge extends to the California sea cucumber Parastichopus californicus, a commercially important fisheries species on the west coast of North America including British Columbia (BC),

() Fisheries and Oceans Canada 2016. Open Access under Creative Commons by Attribution Licence. Use, distribution and reproduction are unrestricted. Authors and original publication must be credited.

Publisher: Inter-Research · www.int-res.com 
Canada. California sea cucumbers are observed in highest densities at depths between 10 and $60 \mathrm{~m}$ on hard substrates such as bedrock, shell or gravel from Baja California to the Gulf of Alaska (Zhou \& Shirley 1996, Lambert 1997, Woodby et al. 2000). Current, salinity and ocean temperature may also play a role in their spatial distribution (Zhou \& Shirley 1996). $P$. californicus is a deposit feeder that consumes detritus by thrusting its tentacles into the substratum and then collapsing them into its mouth (Cameron \& Fankboner 1984). Some reports have also described suspension feeding either through the mouth (Da Silva et al. 1986) or by pumping water through the anus (Jaeckle \& Strathmann 2013). This species is suspected to feed continuously while moving nondirectionally (Da Silva et al. 1986, Cieciel 2004), although while feeding it displays particle selectivity, preferentially ingesting material with high organic content (Ahlgren 1998, Paltzat et al. 2008). California sea cucumbers exhibit an escape response to the presence of some sea stars, especially Pycnopodia helianthoides, although evidence suggests that only juveniles are vulnerable to predation (Margolin 1976, Cameron \& Fankboner 1989).

The dive fishery for $P$. californicus in BC began in 1980. There are currently 85 licenses in the industry with a total allowable catch (TAC) of $\sim 600000 \mathrm{~kg}$ split weight (water removed) (DFO 2013) and a wholesale value of $\sim$ CAD $\$ 10.8$ million (ca. USD $\$ 7.56$ million) (BC Ministry of Agriculture 2012) in 2011. Recent price increases for wild-caught P. californicus have piqued interest in sea cucumber aquaculture. In BC, various shellfish and finfish culture proponents are interested in benthic ranching of sea cucumbers at existing aquaculture sites via seeding of either hatchery-produced or wild-set juveniles collected from existing shellfish (oyster, mussel, scallop) grow-out gear. The premise is that the increased organic loading (i.e. food for the sea cucumbers) underneath these sites will increase growth/survival rates of the animals. A potential benefit of this form of culture, often referred to as integrated multi-trophic aquaculture, is that the sea cucumbers (deposit feeders) help ameliorate the increased organic level and facilitate nutrient cycling via their feeding (e.g. Uthicke 1999, Chang et al. 2004, Paltzat et al. 2008, Slater \& Carton 2009, Martinez-Porchas et al. 2010, Hannah et al. 2013). In addition, the physical act of sediment bioturbation by sea cucumbers can also further facilitate nutrient cycling (Michio et al. 2003, MacTavish et al. 2012). Some proponents of sea cucumber aquaculture believe that the increased food supply at existing aquaculture sites will be suf- ficient to retain cultured sea cucumbers within the boundaries of the tenure and that no physical containment will be required (C. M. Pearce pers. obs.). Even if emigration of cultured sea cucumbers away from the site were limited or non-existent, there are concerns about the level of immigration of wild sea cucumbers onto the tenure. If wild individuals are attracted to aquaculture sites by increased organic levels, they could potentially be harvested as cultured product. This is a major concern for the management of the wild fishery, and there is a strong incentive to have a better understanding of sea cucumber movements in and around aquaculture sites.

Animals typically restrict foraging to areas that provide the best habitat or resource availability while reducing the risk of predation (Lima 1985, Bell 1990, Mysterud \& Ims 1998). When foraging in a relatively homogeneous area, however, random or non-directional movement is common because it reduces the probability of encountering the same resource twice without relying on memory (Pyke 1978). Many species display random foraging behaviour, but change their search strategy in response to food availability or preference to best exploit the resources that are available (Zimmerman 1979, McClintock \& Lawrence 1985, Wolf \& Hainsworth 1991, Beddingfield \& McClintock 1993). Some deposit-feeding sea cucumbers, such as Stichopus spp., Australostichopus mollis and $H$. sanctori, show a high degree of patch selectivity based on total organic matter (TOM) in the sediments, whereas others, such as some Holothuria species, appear to show no preference (Uthicke \& Karez 1999, Slater et al. 2011, Navarro et al. 2013, 2014). Although movement has been observed to be non-directional in P. californicus (Da Silva et al. 1986, Cieciel 2004), it is unknown whether they exhibit patch selectivity along a heterogeneous substrate. The sediment beneath aquaculture tenures is enriched by organic particulates that fall as a result of biodeposition (Haven \& MoralesAlamo 1966, Kautsky \& Evans 1987, Grant et al. 1995, Carroll et al. 2003). If $P$. californicus shows strong patch selectivity, high-TOM areas may attract animals from the surrounding area, making it difficult to separate immigrating wild sea cucumbers from cultured individuals. In this laboratorybased study, we investigated the foraging behaviour of California sea cucumbers in response to different levels of sediment TOM to determine whether they cue in on high organic concentrations and how changes in organic levels in sediments affect their movement. 


\section{MATERIALS AND METHODS}

\section{Animal collection and holding}

Adult California sea cucumbers with a contracted length of $202 \pm 2 \mathrm{~mm}$ (mean $\pm \mathrm{SE}, \mathrm{n}=280$ ) and a contracted width of $73 \pm 1 \mathrm{~mm}$ (mean $\pm \mathrm{SE}, \mathrm{n}=280$ ) were collected by SCUBA at Hudson Rocks, BC $\left(49^{\circ} 13^{\prime} 31.58^{\prime \prime} \mathrm{N}, 123^{\circ} 55^{\prime} 31.63^{\prime \prime} \mathrm{W}\right)$ between April and July 2013. Animals were taken to the Pacific Biological Station (PBS) in Nanaimo, BC, in insulated coolers filled with seawater and held in outdoor circular tanks (diameter $\times$ height: $3 \times 1.5 \mathrm{~m}$ ) supplied with sand-filtered, UV-sterilized, flow-through seawater for 1 to $4 \mathrm{wk}$ prior to experimentation. They were fed ground fish food (either Taplow Black Cod Feed or EWOS Pacific Complete Feed for Salmonids) and masonry sand. These diets were chosen based on commercial availability, pricing, ease of handling and storage and preliminary studies undertaken to ensure their palatability. Prior to commencing a trial, sea cucumbers were isolated from the general population and starved for $48 \mathrm{~h}$ to standardize hunger levels.

\section{Foraging experiment}

To test the effects of food availability on foraging behaviour, we considered 3 levels of TOM in sediment: 'High', 'Medium' and 'Low'. The High treatment $(\sim 8.0 \%$ TOM $)$ was intended to reflect the organic matter level in the sediment (upper $3 \mathrm{~cm}$ ) under a shellfish farm in Village Bay, BC, that had a relatively high density of wild Parastichopus californicus. The TOM concentration in the Medium treatment $(\sim 4.4 \%)$ was consistent with a control site in Village Bay that was not impacted by the shellfish farm. Finally, the Low treatment $(\sim 1.4 \%$ TOM) was the background level of TOM in the experimental sand. Different levels of sediment TOM in the High and Medium treatments were created by mixing finely ground $(1 \mathrm{~mm})$ fish feed, the same as used in the holding tanks, with masonry sand. The Low treatment was simply masonry sand alone with no fish food added. In similar experiments on Holothuria sanctori, Navarro et al. (2013) also manipulated organic matter levels by the addition of fish feed. Experimental tanks (diameter $\times$ height: $3 \times 1.5 \mathrm{~m}$ ) were divided in half and the sediment was placed on either side, similar to experimental trials done by Slater et al. (2011) examining the feeding selectivity of juvenile Australostichopus mollis. No sediment was placed around the $0.4 \mathrm{~m}$ corrugated plastic drain cover in the centre. One of 4 different combinations of TOM was placed within a tank: High-High $(\mathrm{HH})$, Low-Low (LL), High-Low (HL) and High-Medium (HM). HL TOM comparisons were made to ensure that any effect of nutrient levels would be detected. An HM TOM comparison was included to test whether the sea cucumbers would still have a preference for High TOM when both sides have organic material added. We chose not to examine the ML comparison since we felt that it would not provide enough additional information about the movement of the animals.

Due to the high and often variable numbers of sea cucumbers found beneath aquaculture sites, 2 levels of animal density were tested: 'High' density was 9 ind. $\operatorname{tank}^{-1}$ (1.27 ind. $\mathrm{m}^{-2}$ ) and 'Low' density was 1 ind. $\operatorname{tank}^{-1}$ (0.14 ind. $\left.\mathrm{m}^{-2}\right)$. Under the shellfish farm in Village Bay, average densities observed ranged between 2 ind. $\mathrm{m}^{-2}$ in the winter and 4.3 ind. $\mathrm{m}^{-2}$ in the summer (D. L. Curtis unpubl. data). The experimental densities were chosen so that if all the sea cucumbers in the High density treatment showed a preference for the High TOM half of the tank, then density within that half of the tank would be within the annual range noted at the farm site. The experiment was a $4 \times 2$ factorial, completely randomized block design. Blocking occurred over time to compensate for any variations in water conditions or seasonal changes in sea cucumber biology/physiology over the 3 mo experimental period. Each treatment combination was replicated 7 times from mid-April to mid-July 2013 with each temporal block containing 1 replicate of each treatment combination in random order.

Two identical, adjacent, outdoor, covered tanks (diameter $\times$ height: $3 \times 1.5 \mathrm{~m}$ ) with $0.3 \mathrm{~m}$ water depth were used for the experiment (Fig. 1). Sand-filtered and UV-treated seawater flowed into each tank at $201 \mathrm{~min}^{-1}$ through a T-shaped inlet at the sediment dividing line, to ensure that both sides of the tank had equal water flow. A red and a white incandescent light were mounted on each side of the tank and surrounded by opaque, corrugated plastic to reduce glare. A natural photoperiod was simulated with white light during the day and red light at night, the latter to allow filming of the animals. Each trial was recorded via time-lapse photography using a GoPro Hero White Edition camera (Woodman Labs) with an image taken every $1 \mathrm{~min}$ for $24 \mathrm{~h}$. Sediment for each level of TOM was uniformly mixed and spread to a depth of $1 \mathrm{~cm}$ on either side of a lead line that divided the tank. The tank was filled slowly through the 
a)

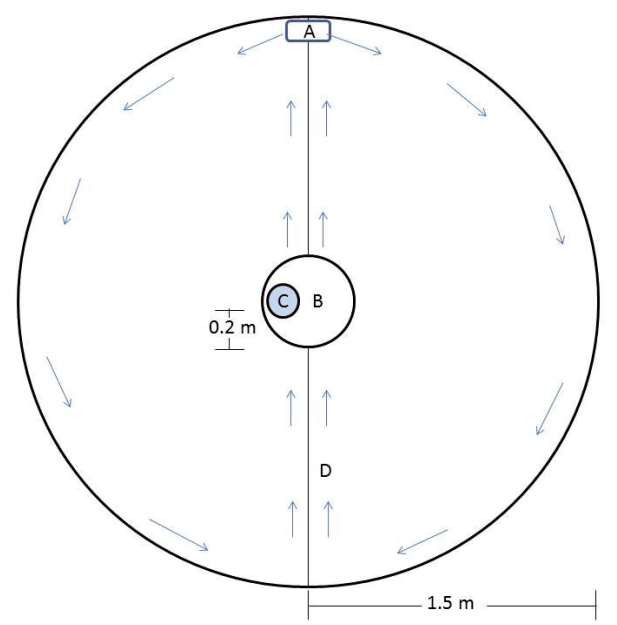

b)

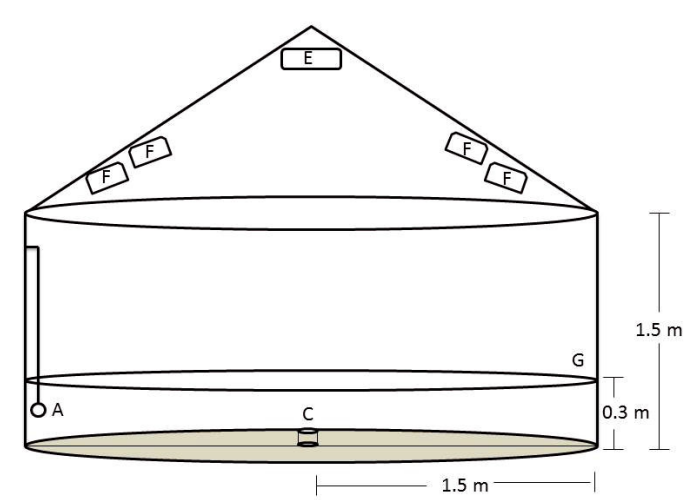

Fig. 1. Set-up of the tanks used for the foraging experiment: (a) aerial view and (b) cross-section. Water flowed from a Tshaped inlet (A) around the tank as shown by the arrows. The tank was divided in half with a lead line (D) along the water flow in the centre. Water drained through a $76.2 \mathrm{~mm}$ diameter PVC drain pipe (C) that was plumbed through a $0.2 \mathrm{~m}$ radius circular Coroplast ${ }^{\mathrm{TM}}$ cover (B) where no sediment was placed. A camera (E) was mounted at the top of the tank, and a red and a white light (F) was placed above each side of the tank. Red light was used to film the animals during the night. Water depth in the tank was $0.3 \mathrm{~m}(\mathrm{G})$

central floor drain to a depth of $0.3 \mathrm{~m}$ to avoid disturbing the sediment and left running overnight prior to the addition of animals. Taplow brand fish feed was used for the first 2 blocks and EWOS for the other 5 . The feeds were assumed equivalent for their effects due to the similarity in their reported proximate composition $(45 \%$ crude protein, $18 \%$ crude fat, $2 \%$ crude fibre).

Immediately prior to each trial, 5 sediment samples were taken from each side of the tank. Samples were dried to a constant weight at $60^{\circ} \mathrm{C}$ for $96 \mathrm{~h}$ and allowed to cool in a desiccator. They were then weighed, ashed for $8 \mathrm{~h}$ at $500^{\circ} \mathrm{C}$, allowed to cool in a desiccator and re-weighed. Percent TOM was calculated based on the difference between the ash weight and the total dry weight and expressed as a percentage of the dry weight, where High $=7.95 \pm$ $0.08 \%$ (mean $\pm \mathrm{SE}, \mathrm{n}=280$ ), Medium $=4.41 \pm 0.09 \%$ $(\mathrm{n}=70)$ and Low $=1.40 \pm 0.01 \%(\mathrm{n}=210)$. After sampling the sediment, temperature $\left(11.2 \pm 0.1^{\circ} \mathrm{C}, \mathrm{n}=\right.$ $56)$, salinity $(31 \pm 0.1)$ and dissolved oxygen $(10.0 \pm$ $0.1 \mathrm{mg} \mathrm{l}^{-1}$ ) in the tanks were measured. Contracted length $(202 \pm 2 \mathrm{~mm}, \mathrm{n}=280)$ and width $(73 \pm 1 \mathrm{~mm})$ of the sea cucumbers were measured before placing them at the centre of the tank. Contracted length and width were measured at the longest and widest parts of the animal, respectively, during contraction. Each experiment was run for $24 \mathrm{~h}$, after which the animals were removed and the tanks were drained, cleaned and the process repeated. In some cases, the treatment did not change between randomized trials, so the sediment was left in the tank (for a maximum of 3 trials in a row). Each animal was used only once during the experiment.

\section{Statistical analyses}

Movement patterns were analysed by tracking the path of the animals along the bottom of the tank over the $24 \mathrm{~h}$ sampling period. Tracking was accomplished using the sport-tracking software Kinovea (www. kinovea.org). Images were sampled every $5 \mathrm{~min}$ at the animal's mouth, and paths were calculated across a Cartesian coordinate in metres, with 0,0 at the centre of the tank and 0,1.5 at the water inlet valve (Fig. 1). Tracking was ceased once the animals reached the wall of the tank, as they rarely left the walls once they were reached. All data were analysed in R 3.0.2 (R Core Team 2013) using the 'Ime4' (Bates et al. 2013) and 'survival' (Therneau 2013) packages.

To test for treatment effects, we looked at how the overall pattern of movement for each animal varied in specific treatment pairings. HH treatments were compared with LL treatments separately from HL and HM. Experiments with a single level of TOM tested differences in a homogeneous substrate, while HL and HM tested the effect of including heterogeneity. For $\mathrm{HH}$ versus LL, the total path length, the mean resultant length for each path and the amount of time spent moving along the sediment before reaching the wall of the tank were analysed. The combination of these variables quantifies the animal's path, giving insight into the differences in foraging behaviour when exposed to different levels of organic matter.

Mean resultant length $R \in[0,1]$ is a measure of the directedness of movement and is related to the Rayleigh test, where 0 is completely random and 1 is 
completely directional (Mardia \& Jupp 2009). It is calculated as the magnitude of the mean direction of movement where $\theta_{i}$ represents the turn angle at time $i$ and

$$
R=\sqrt{\left[\frac{1}{n} \sum_{i=1}^{n} \cos \left(\theta_{i}\right)\right]^{2}+\left[\frac{1}{n} \sum_{i=1}^{n} \sin \left(\theta_{i}\right)\right]^{2}}
$$

Box-Cox transformations (Box \& Cox 1964) were used to transform the total path length and mean resultant length to approximately normal, before using a linear mixed-effects regression with normally distributed random effects to account for interactions between animals within a single tank (Hurlbert 1984, Zuur et al. 2009). These models are analogous to repeated-measures ANOVA. However, regression was chosen because it generalizes easily to different parametric assumptions, allowing for consistency in the analyses. Blocking was also included as a normally distributed random effect. Time spent moving along the sediment before reaching the edge of the tank was analysed using a Cox proportional hazards model with a frailty term, equivalent to a random effect in a mixed-effects model (Therneau \& Grambsch 2000).

In the HL versus HM comparisons, interest was in any preferential behaviour towards the side with higher levels of organic matter. To test this, the proportion of time spent on the side with higher level of organic matter and the proportion of total distance travelled on that side were analysed. For both proportions, a linear mixed-effects regression with normal errors was performed.

In all linear regressions, normal, homogeneous, mean-0 error terms were checked graphically. Satterthwaite approximations were used to calculate degrees of freedom and estimate $\mathrm{p}$-values (Satterthwaite 1946). The effects of different levels of TOM, density and their interaction were estimated for each model. The fixed treatment effects were tested at a significance level of $\alpha=0.05$. If a term was insignificant, it was dropped from the model and reported, and all significant terms were included in the final model.

\section{RESULTS}

\section{General}

After being placed in the centre of the tank, Parastichopus californicus displayed an initial adjustment period of small shifting, reaching a distance of $0.5 \mathrm{~m}$ from the centre by $1.5 \pm 0.2 \mathrm{~h}$. After this, the sea cucumbers displayed more pronounced movements before most reached the wall of the tank and remained there for the duration of the trial. Of the 280 sea cucumbers tested, 258 reached the wall of the tank within $24 \mathrm{~h}$. The distribution of the final positions of the animals after $24 \mathrm{~h}$ was centered on either side of the water inlet valve (Fig. 1). Representative examples of observed paths are shown for each treatment combination (Fig. 2). In all trials and treatments, including those where no additional organic matter was added, animals were observed processing the sediment, as evidenced by them actively placing their tentacles onto the substrate and moving them to their mouth, as well as the presence of faecal material in the tank at the end of the trial.

\section{HH versus LL}

The linear mixed-effects regression on the logtransformed distance travelled showed a significant decrease at Low TOM levels (estimated effect \pm SE: $-0.72 \pm 0.12, \mathrm{p}<0.001)$ and High density $(-0.34 \pm$ $0.17, \mathrm{p}=0.049)$, but no significant interaction between the 2 factors $(-0.51 \pm 0.33, p=0.123)$. Sea cucumbers travelled a significantly longer distance over the sediment before reaching the tank wall for $\mathrm{HH}$ than for LL and a significantly longer distance when held at a low density ( 1 animal tank ${ }^{-1}$ ) than at a high density (9 animals tank ${ }^{-1}$; Fig. 3a).

The linear mixed-effects regression on the powertransformed mean resultant length $\left(\mathrm{R}^{1 / 4}\right)$ showed that as TOM increased from LL to $\mathrm{HH}$, mean resultant length significantly decreased (estimated effect $\pm \mathrm{SE}$ : $-0.13 \pm 0.02, p<0.001)$. Density $(0.04 \pm 0.03, p=0.29)$ and the interaction between TOM and density $(-0.01$ $\pm 0.07, p=0.88$ ) had no significant effect. A decrease in mean resultant length means a decrease in the directedness of movement, so sea cucumber movement in the $\mathrm{HH}$ treatment was significantly more random than that in the LL treatment (Fig. 3b).

A proportional hazards model with frailty showed no significant effect of TOM (estimated effect \pm SE: $-0.50 \pm 0.31, p=0.11)$, density $(-0.39 \pm 0.34, p=0.26)$ or an interaction between the 2 factors $(-0.59 \pm 0.74$, $\mathrm{p}=0.42$ ) on the amount of time it took a sea cucumber to reach the wall of the tank (Fig. 3c).

\section{HL versus HM}

A linear mixed-effects regression on the proportion of distance animals travelled on the High TOM side of the tank indicated no significant effect of HL versus 

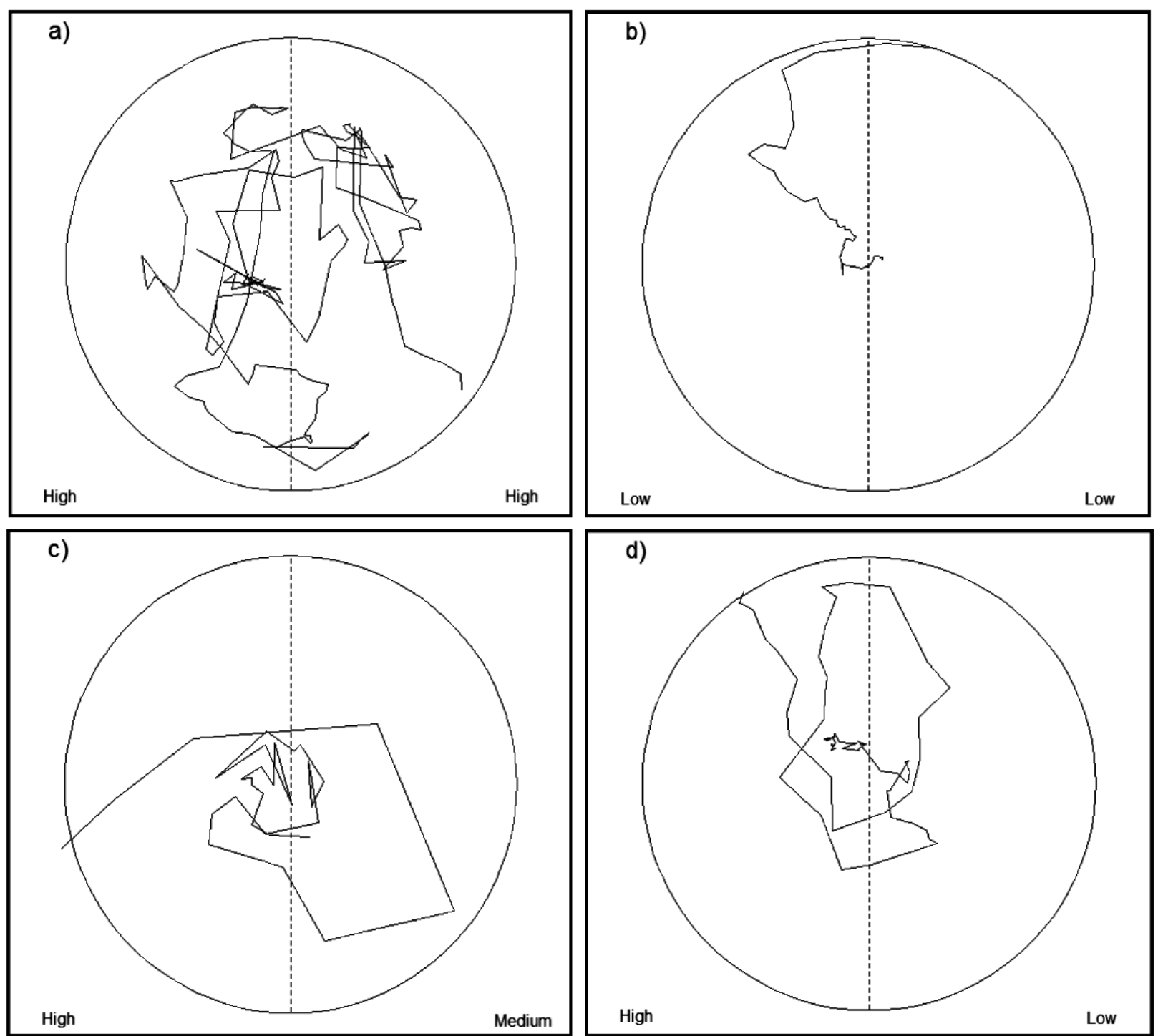

Fig. 2. Types of paths along which California sea cucumbers Parastichopus californicus travelled (all panels with high densities of individuals, i.e. 9 ind. tank $\left.^{-1}\right)$ : (a) only high levels ( 8\%) of total organic matter (TOM), (b) only low levels of TOM ( 1.4\%), (c) high and medium ( $4.4 \%$ ) levels of TOM and (d) high and low levels of TOM. The dashed vertical line represents the division between TOM treatments. These paths were chosen as they show extremes of any significant differences observed in the data

$\mathrm{HM}$ (estimated effect $\pm \mathrm{SE}: 0.04 \pm 0.06, \mathrm{p}=0.53$ ), density $(0.07 \pm 0.07,0.32)$ or an interaction between the 2 factors $(0.06 \pm 0.14, p=0.66)$. The estimated proportion of distance travelled on the High TOM side was not significantly different from $50 \%(\hat{\mathrm{p}}=0.52 \pm 0.03)$. These results indicate that the distance travelled on either side of the tank was equivalent (Fig. 4a).

A linear mixed-effects regression on the proportion of time animals travelled on the High TOM side of the tank found no significant effect of HL versus HM (estimated effect $\pm \mathrm{SE}$ : $0.02 \pm 0.06, p=0.74$ ), density $(0.07 \pm 0.07, p=0.32)$ or an interaction between TOM and density $(-0.03 \pm 0.15, p=0.85)$. The estimated proportion of time travelled on the High TOM side was not significantly different from $50 \%(\hat{p}=0.51 \pm$ $0.03)$. There was no evidence that the animals spent more time on any particular side of the tank (Fig. 4b).

\section{DISCUSSION}

In the wild, the distribution of Parastichopus californicus reflects both current and substrate conditions (Zhou \& Shirley 1996, Woodby et al. 2000). Our study showed similar results; animals favoured areas with a hard vertical surface and moderate current 

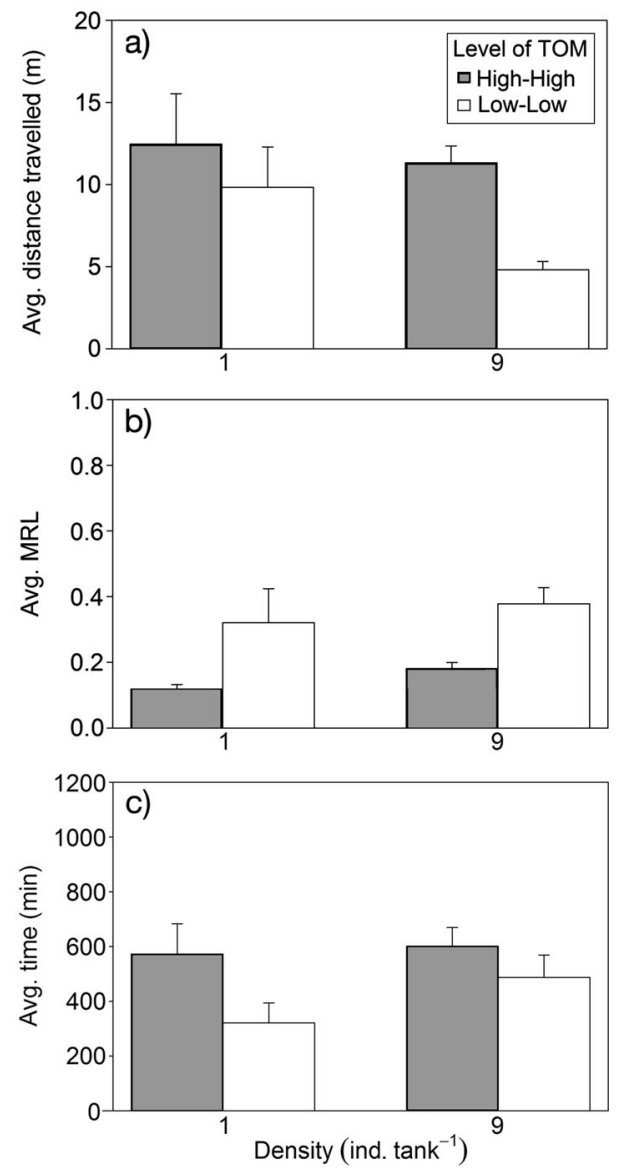

Fig. 3. (a) Average distance travelled by California sea cucumbers Parastichopus californicus, (b) average mean resultant length (MRL; see 'Statistical analyses; Materials and methods' for details) and (c) average time spent moving along the bottom of the tank in response to level of total organic matter (TOM) and sea cucumber density (ind. tank $^{-1}$ ). Results are for foraging experiments with a single level of TOM within a tank. Values are mean \pm SE $(n=7)$.

TOM levels: high, $\sim 8 \%$; medium, $\sim 4.4 . \%$; low, $\sim 1.4 \%$

flow. These effects were similar regardless of the level of TOM in the sediments, with almost all of the animals ending up on the side of the tank within $24 \mathrm{~h}$. For this reason, nutrient loading alone may not be enough to retain a population of sea cucumbers in an area if the substrate and oceanographic conditions are unsuitable.

When presented with high levels of TOM in the sediment, sea cucumbers displayed more random movement than when TOM levels were low. This type of behaviour would keep an animal in areas with high TOM and bring nearby animals to the same sites, ensuring that new resources are encountered (Pyke 1978, Zimmerman 1979). This behaviour results in patch selectivity, where more animals are found feeding on sediments with higher levels of
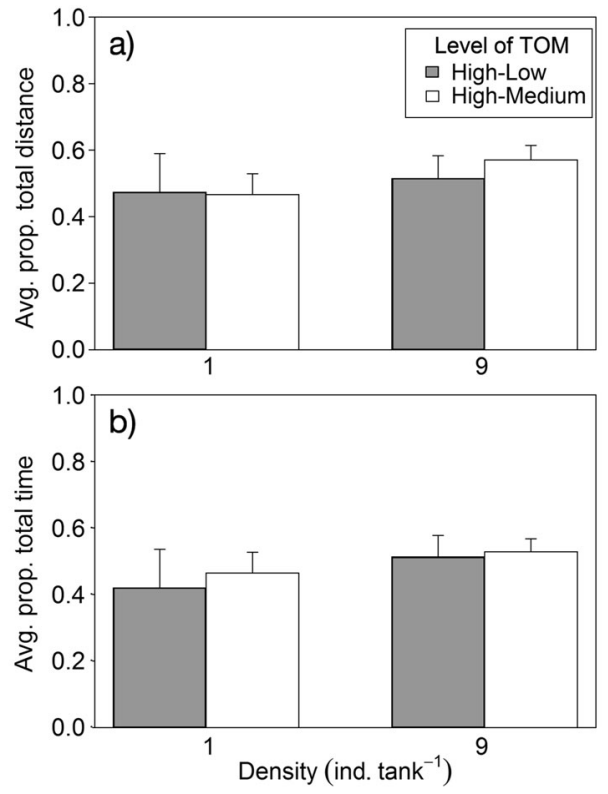

Fig. 4. (a) Average proportion of total distance travelled by California sea cucumbers Parastichopus californicus on the high total organic matter (TOM) side of the tank and (b) average proportion of total time spent moving on the high TOM side of the tank in response to the level of TOM and sea cucumber density (ind. tank ${ }^{-1}$ ). Results are for foraging experiments with 2 levels of TOM within a tank. Values are mean \pm SE $(n=7)$. TOM levels: high, $\sim 8 \%$; medium, $\sim 4.4 . \%$; low, $\sim 1.4 \%$

organic matter than the surrounding area, as has been seen with Stichopus chloronotus, S. variegatus, Australostichopus mollis and Holothuria scabra (Mercier et al. 1999, Uthicke \& Karez 1999, Slater et al. 2011). The sea cucumber $H$. sanctori and other echinoderms, such as sea stars, have also shown similar foraging behaviour, moving more randomly in areas with high food availability (McClintock \& Lawrence 1985, Beddingfield \& McClintock 1993, Navarro et al. 2013). Sea cucumbers in the low-nutrient environments moved slower along shorter, more direct paths. This can be explained by particle selectivity (Ahlgren 1998, Paltzat et al. 2008, Zamora \& Jeffs 2011), whereby it would take more time in each location to process the sediment when there is a lower percentage of organic material available. Although we found no significant effect of density on the randomness of movement, the observed shorter path lengths and similar time spent moving suggests that at high densities, movement may still be more directed than at low densities. Stocking density has been shown to have an impact on growth rates, which could be due to resource limitation in confined areas (Battaglene et al. 1999, Slater \& Carton 2007, Hannah et al. 2013). A change in foraging behaviour may help prevent 
resource limitation at higher densities and is an important consideration for aquaculturists when determining appropriate stocking densities in sea ranching.

Movement along a homogeneous substrate may be non-directional (Da Silva et al. 1986, Cieciel 2004), but this study showed that the amount of directionality can vary depending on food availability. When presented with 2 different levels of TOM within a single tank, however, animals showed no preference for the side of the tank with higher levels of TOM. $P$. californicus is capable of suspension feeding and may be able to detect cues in the water column, similar to other suspension-feeding sea cucumbers (Fankboner 1978, Hamel \& Mercier 1998). If the animals within a tank detect high TOM in the vicinity, random movement would explain the lack of preference for a side of the tank. This highlights the difficulties of applying laboratory results to the field where the acuteness of a gradient can have drastic effects on behaviour (Bell et al. 2003).

Sea cucumbers have been shown to occur over a long period of time in areas that are organically enriched, including beneath aquaculture sites, and are able to assimilate the nutrients these areas provide (van Dover et al. 1992, Ahlgren 1998, Slater \& Carton 2010). Although the experiments in the present study were run in a relatively short period of $24 \mathrm{~h}$, they may partly explain the large congregations of sea cucumbers that are often observed in the highTOM areas beneath aquaculture farms, particularly during the summer months. However, P. californicus displays seasonal atrophy (Fankboner \& Cameron 1985) and is suspected of migrating to deeper water during the winter (Cieciel 2004), similar to other species of sea cucumbers (Hamel \& Mercier 1996, Mercier et al. 2000). During winter months, the density of sea cucumbers beneath the Village Bay shellfish farm drastically decreases (D. L. Curtis pers. obs.). These observations likely reflect seasonal migration as has been reported for non-impacted areas (Cieciel 2004), but are also likely exacerbated by decreased levels of biodeposition and a resulting switch to directed movement away from the farm.

Aquaculture of $P$. californicus has the potential to become a major industry in BC due to the increasing global demand and rising prices for sea cucumbers. However, techniques for sea ranching will need to be adapted to be suitable for this species and to ensure the separation of cultured and wild populations if desired. Based on random movement along the substrate while feeding in high-TOM areas and more directed movement in areas with low levels of TOM, animals should remain beneath an aquaculture site over short periods of time if stocking densities are within a range that maintains random movement. However, over longer periods this may not be true, as has been seen with seasonal fluctuations of densities beneath a shellfish farm (D. L. Curtis pers. obs.). Further research in the field should examine movement of wild and cultured sea cucumbers on and off shellfish and finfish tenures in response to increased organic loading to assess the ultimate feasibility of sea ranching.

Acknowledgements. Funding was provided by Fisheries and Oceans Canada's Aquaculture Collaborative Research and Development Program, Viking Bay Ventures and the Klahoose Shellfish Limited Partnership. We thank Dominique Bureau, Allie Byrne, Lyanne Curtis, Nicholas Duprey, Mica Grant Hagen, Holly Hicklin, Devan Johnson, Laurie Keddy, Bob Kennedy, Jeff Lowe, Ted Sweeten and Masha Zalyvadna for helping with various aspects of the project. P.V.D.-B. was also supported by a University of Victoria graduate student fellowship.

\section{LITERATURE CITED}

Ahlgren M (1998) Consumption and assimilation of salmon net pen fouling debris by the red sea cucumber Parastichopus californicus: implications for polyculture. J World Aquacult Soc 29:133-139

Anderson SC, Flemming JM, Watson R, Lotze HK (2011) Serial exploitation of global sea cucumber fisheries. Fish Fish 12:317-339

Bates D, Maechler M, Bolker B, Walker S (2013) lme4: Linear mixed-effects models using Eigen and S4. R package version 1.0-5. CRAN.R-project.org/package=lme4

Battaglene SC, Seymour JE, Ramofafia C (1999) Survival and growth of cultured juvenile sea cucumbers, Holothuria scabra. Aquaculture 178:293-322

BC Ministry of Agriculture (2012) British Columbia seafood industry year in review 2011. www.env.gov.bc.ca/omfd/ reports/Seafood-YIR-2011.pdf (accessed on 14 March 2014)

Beddingfield SD, McClintock JB (1993) Feeding behavior of the sea star Astropecten articulatus (Echinodermata: Asteroidea): an evaluation of energy-efficient foraging in a soft-bottom predator. Mar Biol 115:669-676

Bell WJ (1990) Searching behavior patterns in insects. Annu Rev Entomol 35:447-467

Bell GW, Eggleston DB, Wolcott TG (2003) Behavioral responses of free-ranging blue crabs to episodic hypoxia. I. Movement. Mar Ecol Prog Ser 259:215-225

Box GEP, Cox DR (1964) An analysis of transformations. J R Stat Soc B 26:211-252

Cameron JL, Fankboner PV (1984) Tentacle structure and feeding processes in life stages of the commercial sea cucumber Parastichopus californicus (Stimpson). J Exp Mar Biol Ecol 81:193-209

> Cameron JL, Fankboner PV (1989) Reproductive biology of the commercial sea cucumber Parastichopus californicus (Stimpson) (Echinodermata: Holothuroidea). II. Observations on the ecology of development, recruitment, and the juvenile life stage. J Exp Mar Biol Ecol 127:43-67 
Carroll ML, Cochrane S, Fieler R, Velvin R, White P (2003) Organic enrichment of sediments from salmon farming in Norway: environmental factors, management practices, and monitoring techniques. Aquaculture 226: 165-180

Chang Y, Yu C, Songxin (2004) Pond culture of sea cucumbers, Apostichopus japonicus, in Dalian. In: Lovatelli A, Conand C, Purcell S, Uthicke S, Hamel JF, Mercier A (eds) Advances in sea cucumber aquaculture and management. FAO Fish Tech Pap 463. FAO, Rome, p 269-272

Chen J (2003) Overview of sea cucumber farming and sea ranching practices in China. SPC Beche Mer Inf Bull 18: 18-23

Cieciel KD (2004) Movement of the giant red sea cucumber Parastichopus californicus in southeastern Alaska. PhD dissertation, University of Alaska, Fairbanks, AK

Conand C (2004) Present status of world sea cucumber resources and utilization: an international overview. In: Lovatelli A, Conand C, Purcell S, Uthicke S, Hamel JF, Mercier A (eds) Advances in sea cucumber aquaculture and management. FAO Fish Tech Pap 463. FAO, Rome, p 13-23

Da Silva J, Cameron JL, Fankboner PV (1986) Movement and orientation patterns in the commercial sea-cucumber Parastichopus californicus (Stimpson) (Holothuroidea, Aspidochritida). Mar Behav Physiol 12:133-147

DFO (Fisheries and Oceans Canada) (2013) Pacific Region integrated fisheries management plan, sea cucumber by dive, October 1, 2013 to September 30, 2014. www.dfompo.gc.ca/fm-gp/peches-fisheries/ifmp-gmp/index-eng. htm (accessed on 27 March 2014)

Fankboner PV (1978) Suspension-feeding mechanisms of the armoured sea cucumber Psolus chitinoides Clark. J Exp Mar Biol Ecol 31:11-25

Fankboner PV, Cameron JL (1985) Seasonal atrophy of the visceral organs in a sea cucumber. Can J Zool 63: 2888-2892

FAO (Food and Agriculture Organization of the United Nations) (2011) Fishery and aquaculture statisticsaquaculture production. FAO yearbook. ftp://ftp.fao.org/ fi/Cdrom/CD_yearbook_2012/navigation/index_content_ aquaculture_e.htm (accessed on 27 March 2014)

Friedman K, Eriksson H, Tardy E, Pakoa K (2011) Management of sea cucumber stocks: patterns of vulnerability and recovery of sea cucumber stocks impacted by fishing. Fish Fish 12:75-93

Grant J, Hatcher A, Scott DB, Pocklington P, Schafer CT, Winters GV (1995) A multidisciplinary approach to evaluating impacts of shellfish aquaculture on benthic communities. Estuaries 18:124-144

Hamel JF, Mercier A (1996) Early development, settlement, growth, and spatial distribution of the sea cucumber Cucumaria frondosa (Echinodermata: Holothuroidea). Can J Fish Aquat Sci 53:253-271

> Hamel JF, Mercier A (1998) Diet and feeding behaviour of the sea cucumber Cucumaria frondosa in the St. Lawrence estuary, eastern Canada. Can J Zool 76: 1194-1198

> Hannah L, Pearce CM, Cross SF (2013) Growth and survival of California sea cucumbers (Parastichopus californicus) cultivated with sablefish (Anoplopoma fimbria) at an integrated multi-trophic aquaculture site. Aquaculture 406-407:34-42

Haven DS, Morales-Alamo R (1966) Aspects of biodeposi- tion by oysters and other invertebrate filter feeders. Limnol Oceanogr 11:487-498

Hurlbert SH (1984) Pseudoreplication and the design of ecological field experiments. Ecol Monogr 54:187-211

> Jaeckle WB, Strathmann R (2013) The anus as a second mouth: anal suspension feeding by an oral deposit-feeding sea cucumber. Invertebr Biol 132:62-68

James DB, Gandhi AD, Palaniswamy N, Rodrigo JX (1994) Hatchery techniques and culture of the sea-cucumber Holothuria scabra. CMFRI Spec Publ 57:1-40

Kautsky N, Evans S (1987) Role of biodeposition by Mytilus edulis in the circulation of matter and nutrients in a Baltic coastal system. Mar Ecol Prog Ser 38:201-212

Lambert P (1997) Sea cucumbers of British Columbia, southeast Alaska, and Puget Sound. University of British Columbia Press, Vancouver

> Lima SL (1985) Maximizing feeding efficiency and minimizing time exposed to predators: a trade-off in the blackcapped chickadee. Oecologia 66:60-67

Lovatelli A, Conand C, Purcell S, Uthicke S, Hamel JF, Mercier A (eds) (2004) Advances in sea cucumber aquaculture and management. FAO Fish Tech Pap 463. FAO, Rome

MacTavish T, Stenton-Dozey J, Vopel K, Savage C (2012) Deposit-feeding sea cucumbers enhance mineralization and nutrient cycling in organically-enriched coastal sediments. PLoS ONE 7:e50031

Mardia KV, Jupp PE (2009) Directional statistics. John Wiley \& Sons, New York, NY

- Margolin AS (1976) Swimming of the sea cucumber Parastichopus californicus (Stimpson) in response to sea stars. Ophelia 15:105-114

- Martinez-Porchas M, Martinez-Cordova LR, PorchasCornejo MA, Lopez-Elias JA (2010) Shrimp polyculture: a potentially profitable, sustainable, but uncommon aquacultural practice. Rev Aquacult 2:73-85

> McClintock JB, Lawrence JM (1985) Characteristics of foraging in the soft-bottom benthic starfish Luidia clathrata (Echinodermata: Asteroidea): prey selectivity, switching behavior, functional responses and movement patterns. Oecologia 66:291-298

Mercier A, Battaglene SC, Hamel JF (1999) Daily burrowing cycle and feeding activity of juvenile sea cucumbers Holothuria scabra in response to environmental factors. J Exp Mar Biol Ecol 239:125-156

> Mercier A, Battaglene SC, Hamel JF (2000) Periodic movement, recruitment and size-related distribution of the sea cucumber Holothuria scabra in Solomon Islands. Hydrobiologia 440:81-100

> Michio K, Kengo K, Yasunori K, Hitoshi M, Takayuki Y, Hideaki Y, Hiroshi S (2003) Effects of deposit feeder Stichopus japonicus on algal bloom and organic matter contents of bottom sediments of the enclosed sea. Mar Pollut Bull 47:118-125

> Mysterud A, Ims RA (1998) Functional responses in habitat use: availability influences relative use in trade-off situations. Ecology 79:1435-1441

> Navarro PG, García-Sanz S, Barrio JM, Tuya F (2013) Feeding and movement patterns of the sea cucumber Holothuria sanctori. Mar Biol 160:2957-2966

- Navarro PG, García-Sanz S, Tuya F (2014) Contrasting displacement of the sea cucumber Holothuria arguinensis between adjacent near shore habitats. J Exp Mar Biol Ecol 453:123-130

Paltzat DL, Pearce CM, Barnes PA, McKinley RS (2008) 
Growth and production of California sea cucumbers (Parastichopus californicus Stimpson) co-cultured with suspended Pacific oysters (Crassostrea gigas Thunberg). Aquaculture 275:124-137

Purcell SW, Mercier A, Conand C, Hamel JF, Toral-Granda MV, Lovatelli A, Uthicke S (2013) Sea cucumber fisheries: global analysis of stocks, management measures and drivers of overfishing. Fish Fish 14:34-59

Pyke G (1978) Are animals efficient harvesters? Anim Behav 26:241-250

R Core Team (2013) R: a language and environment for statistical computing. R Foundation for Statistical Computing, Vienna

Robinson G (2013) A bright future for sandfish aquaculture. World Aquacult 44:18-24

Satterthwaite FE (1946) An approximate distribution of estimates of variance components. Biometrics Bull 2:110-114

Schwerdtner Máñez KS, Ferse SCA (2010) The history of Makassan trepang fishing and trade. PLoS ONE 5: e11346

Slater MJ, Carton AG (2007) Survivorship and growth of the sea cucumber Australostichopus (Stichopus) mollis (Hutton 1872) in polyculture trials with green-lipped mussel farms. Aquaculture 272:389-398

Slater MJ, Carton AG (2009) Effect of sea cucumber (Australostichopus mollis) grazing on coastal sediments impacted by mussel farm deposition. Mar Pollut Bull 58: 1123-1129

Slater MJ, Carton AG (2010) Sea cucumber habitat differentiation and site retention as determined by intraspecific stable isotope variation. Aquacult Res 41:695-702

Slater M, Andrew G, Sewell M (2011) Organically selective movement and deposit-feeding in juvenile sea cucumber, Australostichopus mollis determined in situ and in the laboratory. J Exp Mar Biol Ecol 409:315-323

Therneau $\mathrm{T}$ (2013) A package for survival analysis in S. $\mathrm{R}$ package version 2.37-4. http://CRAN.R-project.org/ package=survival

Therneau TM, Grambsch PM (2000) Modeling survival data: extending the Cox model. Springer, New York, NY

Editorial responsibility: Alejandro Buschmann,

Puerto Montt, Chile
Uthicke S (1999) Sediment bioturbation and impact of feeding activity of Holothuria (Halodeima) atra and Stichopus chloronotus, two sediment feeding holothurians, at Lizard Island, Great Barrier Reef. Bull Mar Sci 64: 129-141

Uthicke S, Karez R (1999) Sediment patch selectivity in tropical sea cucumbers (Holothurioidea: Aspidochirotida) analysed with multiple choice experiments. J Exp Mar Biol Ecol 236:69-87

van Dover CL, Grassie JF, Fry B, Garritt RH, Starczak VR (1992) Stable isotope evidence of entry of sewagederived organic material into a deep-sea food web. Nature 360:153-156

Wang R, Cheng Y (2004) Breeding and culture of the sea cucumber, Apostichopus japonicus, Liao. In: Lovatelli A, Conand C, Purcell S, Uthicke S, Hamel JF, Mercier A (eds) Advances in sea cucumber aquaculture and management. FAO Fish Tech Pap 463. FAO, Rome, p 277-286

> Wolf LL, Hainsworth FR (1991) Hummingbird foraging patterns: visits to clumps of Ipomopsis aggregata inflorescences. Anim Behav 41:803-812

Woodby D, Smiley S, Larson R (2000) Depth and habitat distribution of Parastichopus californicus near Sitka, Alaska. Alsk Fish Res Bull 7:22-32

Yang H, Hamel JF, Mercier A (2015) The sea cucumber Apostichopus japonicus. History, biology, and aquaculture. Academic Press, San Diego, CA

Zamora LN, Jeffs AG (2011) Feeding, selection, digestion and absorption of the organic matter from mussel waste by juveniles of the deposit-feeding sea cucumber, Australostichopus mollis. Aquaculture 317:223-228

Zhou S, Shirley T (1996) Habitat and depth distribution of the red sea cucumber Parastichopus californicus in a southeast Alaska bay. Alaska Fish Res Bull 3:123-131

Zimmerman M (1979) Optimal foraging: a case for random movement. Oecologia 43:261-267

Zuur A, Ieno EN, Walker N, Saveliev AA, Smith GM (2009) Mixed effects models and extensions in ecology with R. Springer Science \& Business Media, New York, NY

Submitted: May 12, 2015; Accepted: October 21, 2015

Proofs received from author(s): January 15, 2016 